\title{
Risk Factors for Adrenal Invasion in Renal Cell Carcinoma
}

\author{
(1) Kaan Çömez MD1, (1) Serdar Çelik MD1, (1) Ozan Bozkurt MD1, (1) Ömer Demir MD1, (1) Güven Aslan MD1, \\ (D) Kutsal Yörükoğlu MD2, (D) ilhan Çelebi MD1 \\ 'Dokuz Eylül University Faculty of Medicine, Department of Urology, lzmir, Turkey \\ ${ }^{2}$ Dokuz Eylül University Faculty of Medicine, Department of Patology, Izmir, Turkey
}

\begin{abstract}
Objective: In this study, we aimed to describe the risk factors associated with adrenal invasion in patients who were diagnosed with renal cell carcinoma (RCC) after radical nephrectomy and identify which risk factors are indications for ipsilateral adrenalectomy (IA).

Materials and Methods: Preoperative (age, gender, tumor side and location, presence of lung metastasis), intraoperative (thrombectomy rate, IA and additional surgery rate), and histopathological data of 298 patients with RCC were reviewed. The patients were divided into 2 groups, those with adrenal invasion and those without, and patient data were compared between these groups. Subsequently, rates of renal sinus invasion, perinephric invasion, and renal vein invasion were evaluated in the T3-4 and T3a patient group and the relationship between these rates and adrenal invasion was investigated.

Results: Adrenal invasion was detected in 8 (2.7\%) of the patients. There were no significant relationships between adrenal invasion and age, gender, tumor side, tumor location, surgery duration, thrombectomy rate, disease stage, sarcomatoid features, microvascular invasion, collecting system invasion, tumor necrosis, or renal vein invasion. The presence of adrenal invasion was associated with a higher rate of additional intraoperative interventions. Adrenal invasion was also significantly associated with greater tumor size, higher pathologic T (pT) stage, and rates of lung metastasis, perinephric invasion, and renal sinus invasion. When stage pT3-4 and pT3a patients were evaluated separately, no significant relation was found between adrenal invasion and renal sinus invasion, perinephric invasion, or renal venous invasion.

Conclusion: PT stage, presence of pulmonary metastasis, and renal sinus invasion were important risk factors for adrenal invasion.

Keywords: Renal cell carcinoma, adrenal invasion, adrenalectomy, radical nephrectomy
\end{abstract}

\section{Introduction}

Renal cell carcinoma (RCC), which accounts for $2-3 \%$ of all cancer cases, is the most common malignant tumor of the kidney (1). Ipsilateral adrenalectomy (IA) with radical nephrectomy was first described by Robson et al. (2) in 1969 to correctly determine the size and spread of the tumor and to improve oncological outcomes in RCC. Later, IA continued to be practiced with radical nephrectomy in order to achieve a wide, intact surgical margin (3). In response to this practice, Lane et al. (4) demonstrated in their study that IA did not significantly impact 5- and 10-year disease-specific or overall survival. In subsequent studies it was reported that the rate of adrenal invasion in patients who undergo nephrectomy with IA is $1-4 \%(5,6,7)$. Therefore, routine IA during nephrectomy is not recommended in these studies, but IA is recommended for patients whose radiological images suggest a large tumor, an upper pole tumor, or adrenal invasion $(5,6,7,8)$. These recommendations indicate that the practice of IA has changed over the years based on the risk-benefit ratio for the patient. However, even if the rate of adrenal invasion is $1-4 \%$, we believe that predicting adrenal invasion provides information that is important for correctly staging patients, gaining insight into prognosis, and creating adjunct therapy and follow-up protocols. Because reducing tumor burden is a facet of RCC treatment, resecting an adrenal gland that has invasion/ 
metastasis becomes even more important. Therefore, in this study we aimed to identify patient risk factors associated with adrenal invasion and to determine which risk factors constitute indications for IA.

\section{Materials and Methods}

Patients who underwent radical nephrectomy between 1995 and 2013 were retrospectively evaluated. Those with a histopathological diagnosis of RCC were included in the study. A total of 298 patients with RCC were evaluated based on preoperative data (age, sex, tumor side, tumor location, presence of lung metastasis), intraoperative data (thrombectomy, IA, and other procedures), and histopathological data [pathological $\mathrm{T}$ (pT) stage, Fuhrman grade, sarcomatoid features, adrenal invasion, microvascular invasion, renal sinus invasion, perinephric invasion, collecting system invasion, tumor necrosis, renal vein and/or vena cava invasion]. The patients were divided into groups based on presence or absence of adrenal invasion and patient data were compared between the groups. The same comparisons were done within the group of patients who underwent IA. We then evaluated rates of renal sinus invasion, perinephric invasion, and renal vein invasion in the T3-4 and T3a patient groups and examined the relationship between these rates and adrenal invasion.

\section{Statistical Analysis}

First, patient data were evaluated by comparing those with and without adrenal invasion using the Mann-Whitney $U$ test for continuous variables and a chi-square test for categorical variables. Kaplan-Meier survival analysis and chi-square test were used to evaluate mortality and survival between groups. Chisquare test was used to compare presence of adrenal invasion and rates of renal sinus invasion, perinephric invasion, and renal vein invasion rates in the T3-4 and T3a patient groups. The Statistical Package for the Social Sciences (SPSS version 20.0; SPSS, Chicago, Illinois, USA) was used for statistical analysis. The data were expressed as mean and standard deviation, and statistical analysis was based on median values. Results with $p$ values $\leq 0.05$ were considered significant.

\section{Results}

The 298 patients who underwent radical nephrectomy had a mean age of $59.2 \pm 11.6(26.5-86.4)$ years. Of these, 85 patients underwent IA, and $8(2.7 \%)$ of those patients had adrenal invasion. There were no cases of adrenal metastasis. The mean follow-up period was $52.3 \pm 35.9$ (1-185.1) months and mean overall survival was $114.4 \pm 5.6$ months. No significant relationship was found between adrenal invasion and sex, tumor side, tumor location, operative time, thrombectomy rate, Fuhrman grade, sarcomatoid features, microvascular invasion, collecting system invasion, tumor necrosis, renal vein invasion, and vena cava invasion (Tables 1 and 2). Additional intraoperative interventions were more common in the presence of adrenal invasion. Presence of adrenal invasion was also associated with significantly greater tumor size (whole group only), pT stage, presence of lung metastasis, and rates of perinephric invasion and renal sinus invasion (Tables 1 and 2).
When pT3-4 and pT3a patients were evaluated separately, no significant relationship was observed between adrenal invasion and renal sinus invasion, perinephric invasion, or renal vein invasion (Table 3).

\section{Discussion}

Performing IA at the time of radical nephrectomy has been a topic of debate for over 25 years (9). The rate of ipsilateral adrenal invasion in patients who undergo radical nephrectomy for RCC is reported to be $<4 \%(5,6,7)$. The rate of adrenal invasion in our study was $2.7 \%$. Current guidelines state that IA during radical nephrectomy does not confer a survival advantage in patients without radiological or intraoperative signs of adrenal invasion and is therefore not recommended for these patients (10).

In a randomized study of 40 patients investigating the perioperative complications of IA in radical nephrectomy, no significant difference was seen in operative time or postoperative complications (11). In our study, the presence of adrenal invasion did not significantly affect operative time.

Many risk factors for predicting adrenal invasion have been identified. It was reported that upper-pole renal tumors $>7$ $\mathrm{cm}$ in size may be associated with adrenal invasion (5). On the other hand, Kutikov et al. (12) pathologically examined IA specimens from 91 patients with $>7 \mathrm{~cm}$ upper-pole renal tumors and found adrenal invasion in only 4 patients (4.4\%). They concluded based on their findings that upper-pole localization is not a predictive factor in RCC (12). There was no significant relationship between adrenal invasion and tumor side or location in our study. However, we observed that adrenal invasion was present in a significant proportion of patients with distant metastasis (lung). This suggests that lung metastasis rates are higher in patients with adrenal invasion due to the advanced tumor stage.

Previous studies examining whether adrenal invasion by RCC occurs via direct extension or through the renal/adrenal veins have emphasized that hematogenous spread may be more common that direct invasion. In a review evaluating this observation, it was reported that left sided primary renal tumors were predominant (62-100\%) among patients with adrenal invasion (5). It was suggested the risk of retrograde tumor embolization was higher on the left side because the adrenal vein drains into the renal vein on that side. However, the multivariate analysis results of other studies within the same review did not support the association between left-sided RCC and adrenal invasion. Due to these contradictory results, it was concluded that RCC laterality cannot be considered an independent risk factor (5). There was also no significant relationship between adrenal invasion and tumor side in our study.

pT stage has also been investigated as a risk factor for adrenal invasion. In a study by Moudouni et al. (13) involving 210 patients, adrenal invasion was detected in 15 patients, 13 of whom were stage T3-4. Similarly, $70 \%$ of the patients with adrenal invasion in our study had at least stage pT3a tumors. When pT3-4 and pT3a patients with renal sinus invasion, renal vein invasion, and perinephric invasion were evaluated 
Çömez et al.

Renal Cell Carcinoma

\begin{tabular}{|c|c|c|c|c|}
\hline & & Adrenal invasion (-) $(n=290)$ & Adrenal invasion $(+)(n=8)$ & $p$ \\
\hline \multicolumn{2}{|l|}{ Age (years) } & $59.2 \pm 11.6$ & $59.6 \pm 10.1$ & 0.924 \\
\hline \multirow[t]{2}{*}{ Gender } & Female & 95 & 3 & \multirow[t]{2}{*}{0.721} \\
\hline & Male & 195 & 5 & \\
\hline \multicolumn{2}{|l|}{ Operative time (minutes) } & $165.2 \pm 61.4$ & $183.8 \pm 43.7$ & 0.219 \\
\hline \multicolumn{2}{|l|}{ Tumor size $(\mathrm{mm})$} & $67.2 \pm 32$ & $98.1 \pm 39.4$ & 0.014 \\
\hline \multirow[t]{2}{*}{ Tumor side } & Right & 143 & 3 & \multirow[t]{2}{*}{0.510} \\
\hline & Left & 147 & 5 & \\
\hline \multirow[t]{3}{*}{ Tumor location } & Upper pole & 102 & 3 & \multirow[t]{3}{*}{0.412} \\
\hline & Mid-pole & 95 & 1 & \\
\hline & Lower pole & 93 & 4 & \\
\hline \multirow[t]{2}{*}{ Lung metastasis } & $(-)$ & 274 & 5 & \multirow[t]{2}{*}{0.000} \\
\hline & $(+)$ & 16 & 3 & \\
\hline \multirow[t]{2}{*}{ Thrombectomy } & $(+)$ & 12 & 1 & \multirow[t]{2}{*}{0.253} \\
\hline & $(-)$ & 278 & 7 & \\
\hline \multirow{2}{*}{$\begin{array}{l}\text { Additional intraoperative } \\
\text { procedure }\end{array}$} & $(+)$ & 18 & 3 & \multirow[t]{2}{*}{0.01} \\
\hline & $(-)$ & 272 & 5 & \\
\hline \multirow[t]{8}{*}{ Pathological stage } & $\mathrm{T} 1 \mathrm{a}$ & 70 & 0 & \multirow[t]{8}{*}{0.012} \\
\hline & $\mathrm{T} 1 \mathrm{~b}$ & 75 & 0 & \\
\hline & $\mathrm{T} 2 \mathrm{a}$ & 52 & 1 & \\
\hline & $\mathrm{T} 2 \mathrm{~b}$ & 21 & 1 & \\
\hline & T3a & 47 & 2 & \\
\hline & $\mathrm{T} 3 \mathrm{~b}$ & 15 & 1 & \\
\hline & T3c & 1 & 0 & \\
\hline & $\mathrm{T} 4$ & 9 & 3 & \\
\hline \multirow[t]{4}{*}{ Fuhrman grade } & 1 & 45 & 0 & \multirow[t]{4}{*}{0.077} \\
\hline & 2 & 131 & 2 & \\
\hline & 3 & 60 & 4 & \\
\hline & 4 & 28 & 1 & \\
\hline \multirow[t]{2}{*}{ Sarcomatoid features } & $(+)$ & 19 & 1 & \multirow[t]{2}{*}{0.507} \\
\hline & $(-)$ & 271 & 7 & \\
\hline \multirow[t]{2}{*}{ Microvascular invasion } & $(+)$ & 43 & 2 & \multirow[t]{2}{*}{0.428} \\
\hline & $(-)$ & 247 & 6 & \\
\hline Renal sinus invasion & $(+)$ & 23 & 4 & 0.003 \\
\hline & $(-)$ & 267 & 4 & \\
\hline Collecting system invasion & $(+)$ & 8 & 1 & 0.112 \\
\hline & $(-)$ & 282 & 7 & \\
\hline Tumor necrosis & $(+)$ & 14 & 1 & 0.342 \\
\hline & $(-)$ & 276 & 7 & \\
\hline Pathologic renal vein invasion & $(+)$ & 25 & 1 & 0.701 \\
\hline & $(-)$ & 265 & 7 & \\
\hline Pathologic vena cava invasion & $(+)$ & 4 & 0 & 0.738 \\
\hline & $(-)$ & 286 & 8 & \\
\hline Perinephric invasion & $(+)$ & 48 & 5 & 0.001 \\
\hline & $(-)$ & 242 & 3 & \\
\hline Overall mortality & & $70(24.1 \%)$ & $5(62.5 \%)$ & 0.014 \\
\hline Overall survival (months) & & $116.1 \pm 5.7$ & $30.1 \pm 9.2$ & $<0.001$ \\
\hline
\end{tabular}


Çömez et al.

Renal Cell Carcinoma

Table 2. Possible risk factors for adrenal invasion in patients who underwent adrenalectomy

\begin{tabular}{|c|c|c|c|c|}
\hline & & Adrenal invasion $(-)(n=77)$ & Adrenal invasion $(+)(n=8)$ & $p$ \\
\hline \multicolumn{2}{|l|}{ Age (years) } & $58.4 \pm 12$ & $59.6 \pm 10.1$ & 0.741 \\
\hline \multirow[t]{2}{*}{ Gender } & Female & 27 & 3 & \multirow[t]{2}{*}{0.891} \\
\hline & Male & 50 & 5 & \\
\hline \multicolumn{2}{|l|}{ Operative time (minutes) } & $178 \pm 61.4$ & $183.8 \pm 43.7$ & 0.556 \\
\hline \multicolumn{2}{|l|}{ Tumor size $(\mathrm{mm})$} & $82 \pm 35.6$ & $98.1 \pm 39.4$ & 0.197 \\
\hline \multirow[t]{2}{*}{ Tumor side } & Right kidney & 34 & 3 & \multirow[t]{2}{*}{0.718} \\
\hline & Left kidney & 43 & 5 & \\
\hline \multirow[t]{3}{*}{ Tumor location } & Upper pole & 34 & 3 & \multirow[t]{3}{*}{0.519} \\
\hline & Mid-pole & 19 & 1 & \\
\hline & Lower pole & 24 & 4 & \\
\hline \multirow[t]{2}{*}{ Lung metastasis } & $(-)$ & 74 & 5 & \multirow[t]{2}{*}{$<0.001$} \\
\hline & $(+)$ & 3 & 3 & \\
\hline \multirow[t]{2}{*}{ Thrombectomy } & $(+)$ & 8 & 1 & \multirow[t]{2}{*}{0.854} \\
\hline & $(-)$ & 69 & 7 & \\
\hline \multirow{2}{*}{$\begin{array}{l}\text { Additional intraoperative } \\
\text { procedures }\end{array}$} & $(+)$ & 8 & 3 & \multirow[t]{2}{*}{0.030} \\
\hline & $(-)$ & 69 & 5 & \\
\hline \multirow[t]{8}{*}{ Pathological stage } & T1a & 5 & 0 & \multirow[t]{8}{*}{0.012} \\
\hline & $\mathrm{T1b}$ & 15 & 0 & \\
\hline & T2a & 21 & 1 & \\
\hline & $\mathrm{T} 2 \mathrm{~b}$ & 10 & 1 & \\
\hline & T3a & 17 & 2 & \\
\hline & $\mathrm{T} 3 \mathrm{~b}$ & 6 & 1 & \\
\hline & T3c & 1 & 0 & \\
\hline & $\mathrm{T} 4$ & 2 & 3 & \\
\hline \multirow[t]{4}{*}{ Fuhrman grade } & 1 & 11 & 0 & \multirow[t]{4}{*}{0.268} \\
\hline & 2 & 34 & 2 & \\
\hline & 3 & 18 & 4 & \\
\hline & 4 & 9 & 1 & \\
\hline \multirow[t]{2}{*}{ Sarcomatoid features } & $(+)$ & 8 & 1 & \multirow[t]{2}{*}{0.854} \\
\hline & $(-)$ & 69 & 7 & \\
\hline \multirow[t]{2}{*}{ Microvascular invasion } & $(+)$ & 19 & 2 & \multirow[t]{2}{*}{0.984} \\
\hline & $(-)$ & 58 & 6 & \\
\hline Renal sinus invasion & $(+)$ & 11 & 4 & 0.012 \\
\hline & $(-)$ & 66 & 4 & \\
\hline Collecting system invasion & $(+)$ & 3 & 1 & 0.274 \\
\hline & $(-)$ & 74 & 7 & \\
\hline Tumor necrosis & $(+)$ & 5 & 1 & 0.528 \\
\hline & $(-)$ & 72 & 7 & \\
\hline Pathologic renal vein invasion & $(+)$ & 12 & 1 & 0.818 \\
\hline & $(-)$ & 65 & 7 & \\
\hline Pathologic vena cava invasion & $(+)$ & 4 & 0 & 0.509 \\
\hline & $(-)$ & 73 & 8 & \\
\hline Perinephric invasion & $(+)$ & 17 & 5 & 0.013 \\
\hline & $(-)$ & 60 & 3 & \\
\hline Overall mortality & & $16(20.8 \%)$ & $5(62.5 \%)$ & 0.009 \\
\hline Overall survival (months) & & $131 \pm 11.8$ & $30.1 \pm 9.2$ & $<0.001$ \\
\hline
\end{tabular}




\begin{tabular}{|c|c|c|c|c|}
\hline \multicolumn{2}{|l|}{ T3a patients $(n=49)$} & $\begin{array}{l}\text { Adrenal } \\
\text { invasion } \\
(-)(n=47)\end{array}$ & $\begin{array}{l}\text { Adrenal } \\
\text { invasion } \\
(+)(n=2)\end{array}$ & $p$ \\
\hline \multirow[t]{2}{*}{ Perinephric invasion } & $(+)$ & 34 & 1 & \multirow[t]{2}{*}{0.493} \\
\hline & $(-)$ & 13 & 1 & \\
\hline \multirow[t]{2}{*}{ Renal sinus invasion } & $(+)$ & 18 & 2 & \multirow[t]{2}{*}{0.082} \\
\hline & $(-)$ & 29 & 0 & \\
\hline \multirow[t]{2}{*}{ Renal vein invasion } & $(+)$ & 10 & 0 & \multirow[t]{2}{*}{0.465} \\
\hline & $(-)$ & 37 & 2 & \\
\hline \multicolumn{2}{|l|}{ T3-4 patients $(n=78)$} & $\begin{array}{l}\text { Adrenal } \\
\text { invasion } \\
(-)(n=72)\end{array}$ & $\begin{array}{l}\text { Adrenal } \\
\text { invasion } \\
(+)(n=6)\end{array}$ & $p$ \\
\hline \multirow[t]{2}{*}{ Perinephric invasion } & $(+)$ & 48 & 5 & \multirow[t]{2}{*}{0.401} \\
\hline & $(-)$ & 24 & 1 & \\
\hline \multirow[t]{2}{*}{ Renal sinus invasion } & $(+)$ & 23 & 3 & \multirow[t]{2}{*}{0.367} \\
\hline & $(-)$ & 49 & 3 & \\
\hline \multirow[t]{2}{*}{ Renal vein invasion } & $(+)$ & 24 & 0 & \multirow[t]{2}{*}{0.089} \\
\hline & $(-)$ & 48 & 6 & \\
\hline
\end{tabular}

in separate subgroups, all groups had similar rates of adrenal invasion. These results suggest that pT3-4 is a risk factor for adrenal invasion, whereas renal sinus, renal vein, and perinephric invasion do not effectively discriminate adrenal invasion on their own. However, the nonsignificance of our findings may be due to the small numbers of patients with adrenal invasion and in the subgroups, which is one of the limitations of this study. When we examined pathological data other than $\mathrm{T}$ stage, we observed no significant association between adrenal invasion and Fuhrman grade, sarcomatoid features, microvascular invasion, collecting system invasion, tumor necrosis, renal vein invasion, or vena cava invasion. Our findings indicate that adrenal invasion is more common only in the presence of perinephric and renal sinus invasion. The possible pathophysiology of this may be related to the higher risk of metastasis in RCC due to the presence of ample venous and lymphatic drainage in the renal sinus (14). However, our review of the literature yielded no study that shows a direct association between adrenal invasion and pathological data other than T stage, especially renal sinus invasion. Perinephric invasion and renal sinus invasion may be signs of advanced disease, which could explain their significant relationship with adrenal invasion. Other than this, overall survival times were lower and mortality rates were higher in patients with adrenal invasion compared to the other patients. This finding is also related to advanced T stage.

\section{Study Limitations}

Cancer-specific survival and metastasis-free survival were not assessed in this study. Due to the adrenal preserving approach developed over the years, the long-term, retrospective nature of the study and the small patient population (especially in the group with adrenal invasion) constitute limitations of this research.

\section{Conclusion}

In summary, the findings of this study indicate that pT stage and the presence of lung metastasis and renal sinus invasion constitute important risk factors for adrenal invasion. However, the necessity of IA in patients with risk factors for adrenal involvement is debatable. It is clear that more extensive prospective studies are needed to bring clarity to this issue.

\section{Ethics}

Ethics Committee Approval: Retrospective study.

Informed Consent: Retrospective study.

Peer-review: Externally peer-reviewed.

\section{Authorship Contributions}

Surgical and Medical Practices: O.B., Ö.D., G.A., I.Ç., Concept: K.Ç., S.Ç., Design: K.Ç., S.Ç., K.Y., Data Collection or Processing: K.Ç., S.Ç., Analysis or Interpretation: K.Ç., S.Ç., K.Y., Literature Search: K.Ç., S.Ç., Writing: K.Ç.

Conflict of Interest: No conflict of interest was declared by the authors.

Financial Disclosure: The authors declared that this study received no financial support.

\section{References}

1. Lindblad P. Epidemiology of renal cell carcinoma. Scand J Surg 2004;93:88-96.

2. Robson CJ, Churchill BM, Anderson W. The results of radical nephrectomy for renal cell carcinoma. J Urol 1969;101:297-301.

3. Mickisch G, Carballido J, Hellsten S, et al. Guidelines on renal cell cancer. Eur Urol 2001;40:252-255.

4. Lane BR, Tiong HY, Campbell SC, et al. Management of the adrenal gland during partial nephrectomy. J Urol 2009;181:2430-2436.

5. O'Malley RL, Godoy G, Kanofsky JA, Taneja SS. The necessity of adrenalectomy at the time of radical nephrectomy: a systematic review. J Urol 2009;181:2009-2017.

6. Weight CJ, Kim SP, Lohse CM, et al. Routine adrenalectomy in patients with locally advanced renal cell cancer does not offer oncologic benefit and places a significant portion of patients at risk for an asynchronous metastasis in a solitary adrenal gland. Eur Urol 2011;60:458-464.

7. Wein AJ KL, Novick AC, et al., eds. Malignant renal tumors. In: Campbell SC LB ed. Campbell-Walsh Urology. Vol 2. 10 ed. Philadelphia,: PA: Saunders Elsevier; 2012. p. 1413-1474.

8. Siemer S, Lehmann J, Kamradt J, et al. Adrenal metastases in 1635 patients with renal cell carcinoma: outcome and indication for adrenalectomy. J Urol 2004;171:2155-2159.

9. Gabr AH, Steinberg Z, Eggener SE, Stuart Wolf J Jr. Indications for adrenalectomy during radical nephrectomy for renal cancer. Arab J Urol 2014;12:304-308.

10. Weight CJ, Mulders PF, Pantuck AJ, Thompson RH. The Role of Adrenalectomy in Renal Cancer. Eur Urol Focus 2016;1:251-257.

11. Hellström PA, Bloigu R, Ruokonen AO, et al. Is routine ipsilateral adrenalectomy during radical nephrectomy harmful for the patient? Scand J Urol Nephrol 1997;31:19-25.

12. Kutikov A, Piotrowski ZJ, Canter DJ, et al. Routine adrenalectomy is unnecessary during surgery for large and/or upper pole renal tumors when the adrenal gland is radiographically normal. J Urol 2011;185:1198-1203.

13. Moudouni SM, En-Nia I, Patard J), et al. Real indications for adrenalectomy in renal cell carcinoma. Scand J Urol Nephrol 2002;36:273-277.

14. Bonsib SM, Gibson D, Mhoon M, Greene GF. Renal sinus involvement in renal cell carcinomas. Am J Surg Pathol 2000;24:451-458. 